\title{
Effectiveness of Audio Visual Media Intervention Aku Bangga Aku Tahu (ABAT) towards Attitude of Street Children in Prevention of HIV \& AIDS Transmission in Makassar City
}

\author{
Nahdiyah; Ida Leida Maria ${ }^{1}$; Yahya Thamrin ${ }^{2}$ \\ ${ }^{1}$ Department of Epidemiology, Faculty of Public Health, Hasanuddin University, Indonesia \\ ${ }^{2}$ Departemen of Occuputional Helath and Safety, Hasanuddin University, Indonesia
}

http://dx.doi.org/10.18415/ijmmu.v6i5.1176

\begin{abstract}
Street children are one of the populations that are vulnerable to HIV transmission and the use of drugs, psychotropic substances, and addictive substances (drugs) because they are in a social, economic and psychological situation that allows such deviant behavior to occur. This study aims to determine the effectiveness of ABAT audio visual media interventions on the attitudes of street children in the prevention of HIV \& AIDS transmission in Makassar City. This study uses an experimental quasy with the Nonequivalent Control Group Design. Sampling using non probability sampling by purposive sampling. The research sample consisted of 48 intervention groups and 47 controls. Data collection took place from June to July 2019. Quantitative data analysis with statistical application of SPSS, using paired T test, Wilcoxon test and mann whitney. The results showed that the average attitude score before and after the intervention, where the mean value $\pm \mathrm{SD}$ was $36.81 \pm 4.489$ to $42.27 \pm 3.174$ with a $\mathrm{p}$ value $(\mathrm{p}=$ $0.000)<0.05$ in the intervention group, and at the mean \pm SD value in the control group was $38.06 \pm$ 4.570 to $44.77 \pm 2.830$ with a $\mathrm{p}$ value $(\mathrm{p}=0.000)<0.05)$ which means that there were significant differences in attitude before and after the ABAT audio-visual media intervention. The results of the mann whitney test show that the ABAT intervention is three times better than just one time with a $\mathrm{p}$ value $(\mathrm{p}=0,000$ and 0.007$)<0.05)$. It can be concluded that the ABAT audio-visual media is effective in improving the attitude of street children in preventing the transmission of HIV \& AIDS. ABAT needs to be recommended as a counseling media for the prevention of HIV \& AIDS transmission among adolescents, especially street children in Makassar.
\end{abstract}

Keywords: Street Children; HIV \& AIDS; ABAT; Attitudes 


\section{Introduction}

HIV stands for Human Immunodeficiency Virus which can cause AIDS by attacking white blood cells called CD4 cells so that it can damage the human immune system that ultimately cannot survive disease even though it is very mild. The HIV virus attacks CD4 cells and turns them into breeding grounds. The new HIV virus then destroys it so that it cannot be used anymore. White blood cells are indispensable for the immune system. Without immunity, the body can be attacked by various diseases which in turn can cause death (Kemenkes RI, 2018).

Around the world at the end of 2017 it was estimated that 36.9 million people were living with HIV and 2.1 million were estimated to be newly infected with HIV with an infection rate of 0.3 new infections per 1000 uninfected people, down from 0.40 per 1000 uninfected population in 2005. The African region remained the most severely affected with an incidence rate of 1.24 per 1000 uninfected population. In the same year an estimated 1 million people died from this disease, 120,000 of whom were children under the age of 15 years (WHO, 2018).

AIDS cases in Indonesia tend to increase until 2013 and then decrease in subsequent years. This is expected because the AIDS case reporting system is still low in various regions. The cumulative number as of June 2018 is 108,829 AIDS cases (Kemenkes RI, 2018).

Transmission of HIV \& AIDS generally starts from risk behaviors that are often found in adults to adolescents (Brooks-Gunn, et al., 1988). One group of adolescents who have a high risk because of their condition that supports deviant behavior is street children (Kruger \& Richter, 2003). Street children are one of the populations that are vulnerable to HIV transmission and the use of drugs, psychotropic substances, and addictive substances (drugs) because they are in a social, economic and psychological situation that allows such deviant behavior to occur. Research in various countries shows high rates of HIV infection in street children due to a tendency to engage in risky behaviors such as free sex, injecting drug use, tattoos, and body piercing (Harjanti \& Wongso, 2017).

Street children are a social problem that is often found in big cities in Indonesia, including Makassar City. Data from the Ministry of Social Affairs in 2015 stated that there were 4.1 million cases of neglected children and 34,000 street children (Harjanti \& Wongso, 2017). The amount tends to be smaller than the existing estimates, on the contrary, there is a tendency that the number is increasing from time to time.

Street children have also not been included in the key population category in the response to HIV \& AIDS so that it receives very little attention in HIV \& AIDS prevention programs in Indonesia. Meanwhile, the government is looking at solving this problem with a short-term approach, namely by conducting raids on the streets and sending them to social institutions. In fact, to protect street children from HIV transmission and drug use, namely through strengthening the life skills of street children and referral to health services, it is necessary to integrate these efforts into a sustainable care approach that prioritizes prevention rather than the orphanage approach (Harjanti and Wongso, 2017).

Strengthening the skills of street children can be done by increasing attitudes about HIV \& AIDS. One government program that aims to increase knowledge and attitudes about HIV and AIDS in the 1524 years age group through the I'm Proud I Know (ABAT) program. ABAT is a campaign to prevent the spread of HIV \& AIDS so that youth groups know and can avoid getting infected with HIV. Therefore the aim of this is to look at the effectiveness of audio-visual media interventions, I'm Proud I Know (ABAT) towards the attitude of street children in the prevention of HIV \& AIDS transmission in Makassar City. 


\section{Methods}

This research uses quasy experimental method with The Nonequivalent Control Group Design. Measurements were made three times using a questionnaire that is once before the intervention and twice after the intervention. This research was conducted in Makassar City, South Sulawesi Province.The population in this study were all street children who have been recorded at the Makassar City Social Service in 2018 as many as 232 people. The total sample consisted of 97 people consisting of 48 intervention group respondents and 47 control group respondents. The study collaborated with two foundations, the Ummi Pabbata Foundation (Yapta-U) and the Institute of Human Studies (LSIC). Respondents were selected through inclusion criteria, namely street children aged 15-18 years and willing to follow the research by signing informed consent.

Data collection in this study was carried out by distributing questionnaires during the pre-test and post-test. The measuring instrument used was the ABAT questionnaire to measure respondents' attitudes consisting of 13 questions. In the intervention group, giving ABAT audio visual media was given three times and the control group once. Pre-test is given after intervention, then post-test is given after two weeks and one month after pre-test. Data is processed using Statistical Package for Social Science (SPSS) 22 for Windows. Quantitative data were analyzed by bivariate analysis using Wilcoxon and Mann Whitney tests to assess the effectiveness of ABAT audio visual media interventions on attitudes about HIV and AIDS in street children.

\section{Results and Discussion}

Univariate Analysis Results

Table 1. Distribution of Respondents by Characteristics in the Intervention and Control Groups

\begin{tabular}{|c|c|c|c|c|c|c|}
\hline \multirow{3}{*}{ Characteristics } & \multicolumn{4}{|c|}{ Street Children } & \multirow{2}{*}{\multicolumn{2}{|c|}{ Total }} \\
\hline & \multicolumn{2}{|c|}{ Intervention } & \multicolumn{2}{|c|}{ Control } & & \\
\hline & n (48) & $\%$ & n (47) & $\%$ & n (95) & $\%$ \\
\hline \multicolumn{7}{|l|}{ Age } \\
\hline 15 years & 18 & 37,5 & 19 & 40,4 & 37 & 39 \\
\hline 16 years & 10 & 20,8 & 11 & 23,4 & 21 & 22 \\
\hline 17 years & 20 & 41,7 & 17 & 36,2 & 37 & 39 \\
\hline \multicolumn{7}{|l|}{ Gender } \\
\hline Male & 28 & 58,3 & 29 & 61,7 & 57 & 60 \\
\hline Female & 20 & 41,7 & 18 & 38,3 & 38 & 40 \\
\hline \multicolumn{7}{|l|}{ Education } \\
\hline Elementary School & 11 & 22,9 & 2 & 4,3 & 13 & 13,7 \\
\hline Junior High School & 37 & 77,1 & 45 & 95,7 & 82 & 86,3 \\
\hline \multicolumn{7}{|l|}{ Occupation } \\
\hline Busker & 12 & 25 & 14 & 29,8 & 26 & 27,4 \\
\hline Parking officers & 8 & 16,7 & 10 & 21,3 & 18 & 18,9 \\
\hline Seller & 18 & 37,5 & 8 & 17 & 26 & 27,4 \\
\hline Not Working & 10 & 20,8 & 15 & 31,9 & 25 & 26,3 \\
\hline
\end{tabular}


Table 1 shows that the characteristics of respondents based on age in the intervention and control groups were mostly at age 15 years and 17 years by 39\% (37 people). Whereas respondents with the age of 16 years are the least amount of $22 \%$ ( 21 people). Based on gender, the majority of respondents were male namely 57 people (60\%) and women as many as 38 people (40\%). As for the education level of respondents, the most at the junior level were 82 people $(86.3 \%)$ and at least at the elementary school level were 13 people (13.7\%). Characteristics of respondents based on work mostly worked as sellers and buskers each by $27.4 \%$ (26 people). While at least work as a parking attendant at $18.9 \%$ (18 people).

Table 2. Distribution of Categories of Risk Behavior and Free Sex on Street Children

\begin{tabular}{lcccc}
\hline \multirow{2}{*}{$\begin{array}{c}\text { Risk Behavior and Free Sex } \\
\text { Categories }\end{array}$} & \multicolumn{4}{c}{ Street children } \\
\cline { 2 - 5 } & \multicolumn{2}{c}{ Intervention } & \multicolumn{2}{c}{ Control } \\
\cline { 2 - 5 } & $\mathbf{n}$ & $\mathbf{\%}$ & $\mathbf{n}$ & $\mathbf{\%}$ \\
\hline $\begin{array}{l}\text { Not good } \\
\text { Wess }\end{array}$ & 6 & 12,5 & 27 & 57,4 \\
& 14 & 29,2 & 17 & 36,2 \\
& 28 & 58,3 & 3 & 6,4 \\
\hline
\end{tabular}

The results of the analysis in table 2 show that the respondents in the intervention group were in the good category at $58.3 \%$ ( 28 people) while the least in the bad category was $12.5 \%$ (6 people). In the control group the most in the bad category was $57.4 \%$ (27 people) while the least in the good category was $6.4 \%$ (3 people).

Table 3. Distribution of Respondents' Attitude Categories Before and After Intervention

\begin{tabular}{|c|c|c|c|c|}
\hline \multirow{3}{*}{ Attitude Category } & \multicolumn{4}{|c|}{ Street children } \\
\hline & \multicolumn{2}{|c|}{ Intervention } & \multicolumn{2}{|c|}{ Control } \\
\hline & $\mathbf{n}$ & $\%$ & $\mathbf{n}$ & $\%$ \\
\hline \multicolumn{5}{|l|}{ Pre Test } \\
\hline Negative $(\leq 32,5)$ & 8 & 16,7 & 10 & 21,3 \\
\hline Positive $(>32,5)$ & 40 & 83,3 & 37 & 78,7 \\
\hline \multicolumn{5}{|l|}{ Post Test 1} \\
\hline Negative $(\leq 32,5)$ & 0 & 0 & 0 & 0 \\
\hline Positive $(>32,5)$ & 48 & 100 & 48 & 100 \\
\hline \multicolumn{5}{|l|}{ Post Test 2} \\
\hline Negative $(\leq 32,5)$ & 0 & 0 & 0 & 0 \\
\hline Positive $(>32,5)$ & 48 & 100 & 48 & 100 \\
\hline
\end{tabular}

Table 3 shows the categories of respondents' attitudes in the intervention group before the intervention in the pre-test was in the positive category of $83.3 \%$ (40 people) while the negative category was $16.7 \%$ (8 people). After the ABAT audio visual media intervention, both post test 1 and post test 2 experienced an overall increase into a positive category. In the control group before the intervention in the 
pre-test also the most was in the positive category of $78.8 \%$ (37 people) while the negative category was $21.3 \%$ (10 people). After the intervention, both post test 1 and post test 2 also experienced an overall increase in positive categories. This shows that there are differences in the categories of respondents' attitudes before and ABAT audio visual media interventions.

Bivariate Analysis Results

Table 4. Differences in the Respondents' Attitudes Before and After Intervention in the Intervention Group Street children

\begin{tabular}{lccccc}
\cline { 2 - 5 } \multicolumn{1}{c}{ Attitude } & $\mathbf{n}$ & $\begin{array}{c}\text { Median } \\
\text { (Min-Max) }\end{array}$ & Mean \pm SD & $\begin{array}{c}\text { Kolmogorof } \\
\text { Smirnov }\end{array}$ & $\boldsymbol{p}$ \\
\hline Pre Test & 48 & $37(26-52)$ & $36,81 \pm 4,489$ & 0,200 & 0,000 \\
Post Test 1 & 48 & $42(36-52)$ & $42,27 \pm 3,174$ & 0,154 & \\
\hline Post Test 1 & 48 & $42(36-52)$ & $42,27 \pm 3,174$ & 0,154 & 0,942 \\
Post Test 2 & 48 & $42,5(35-52)$ & $42,25 \pm 3,265$ & 0,200 & \\
\hline
\end{tabular}

Table 5. Differences in the Respondents' Attitudes Before and After Intervention in the Control Group Street children

\begin{tabular}{lccccc}
\cline { 2 - 5 } Attitude & $\mathbf{n}$ & $\begin{array}{c}\text { Median } \\
\text { Min-Max) }\end{array}$ & Mean \pm SD & $\begin{array}{c}\text { Kolmogorof } \\
\text { Smirnov }\end{array}$ & $\boldsymbol{p}$ \\
\hline Pre Test & 47 & $39(27-44)$ & $38,06 \pm 4,570$ & 0,000 & 0,000 \\
Post Test 1 & 47 & $45(39-51)$ & $44,77 \pm 2,830$ & 0,200 & \\
\hline Post Test 1 & 47 & $45(39-51)$ & $44,77 \pm 2,830$ & 0,200 & 0,006 \\
Post Test 2 & 47 & $44(37-52)$ & $43,89 \pm 2,807$ & 0,039 & \\
\hline
\end{tabular}


Table 6. Differences in the Effectiveness of ABAT Three Times and One Time Against the Respondents' Attitudes

\begin{tabular}{|c|c|c|c|}
\hline \multirow{2}{*}{ Attitude } & \multicolumn{3}{|c|}{ Street children } \\
\hline & Post Test 1 & Post Test 2 & p*value \\
\hline \multicolumn{4}{|l|}{ Intervention } \\
\hline Min & 36 & 35 & \\
\hline $\operatorname{Max}$ & 52 & 52 & 0,942 \\
\hline Mean & 42,27 & 42,25 & \\
\hline Standard Deviation & $\pm 3,174$ & $\pm 3,265$ & \\
\hline \multicolumn{4}{|l|}{ Control } \\
\hline Min & 51 & 52 & \\
\hline Max & 44,77 & 43,89 & 0,006 \\
\hline Mean & $\pm 2,830$ & $\pm 2,807$ & \\
\hline Standard Deviation & & & \\
\hline$p^{* *}$ value & 0,000 & 0,007 & \\
\hline
\end{tabular}

Bivariate test results in this study are shown in table 4 and table 5 . Based on the results of the analysis using the Wilcoxon test, the significance value was $0,000(\mathrm{p}<0.05)$ in the intervention group and the significance value was $0,000(\mathrm{p}<0.05)$ in the control group. Thus it can be concluded that there are differences in attitude before and after ABAT audio-visual media intervention three times and once. The results of the mann whitney test show that the ABAT intervention was three times better than just one time with a $\mathrm{p}$ value $(\mathrm{p}=0,000)<0.05)$ on post test 1 and a $\mathrm{p}$ value $(\mathrm{p}=0.007)<0.05)$ on post test 2 .

Based on the analysis of risk behavior and free sex shows that of the 95 respondents, there were 33 respondents who were in the bad category and 32 respondents who were in the poor category. The staged behavior is sexual intercourse before marriage and drug use. Sexual intercourse that starts from kissing, groping, having sex to having same-sex sex. This behavior is quite risky to transmit various diseases such as sexually transmitted infections including HIV \& AIDS. This is in line with research conducted by Amiruddin and Yanti (2013) that sexual relations carried out by street children in Makassar City are very alarming. This is because 100 people (36.9\%) of the 271 street children in this study showed that they had taken a risk of contracting HIV \& AIDS, sexual intercourse carried out not only vaginally, even orally or anal.

The risky behavior of street children from the researchers' point of view is very worrying. Things like kissing and sex are common among street children. Even sexual intercourse with multiple partners is often done. This happens because the mobilization of street children is high enough to move from one city to another. One respondent even claimed to have several "girlfriends" and had biological relations. The most astonishing thing for researchers is that some street children who are female choose to become commercial sex workers (CSWs) if they are short of money. 
The next risk action is the use of drugs. Based on the results of the analysis, there were $9.5 \%$ of street children who had previously carried out gluing activities (inhalation activities) and as many as $8.4 \%$ of respondents had used drugs. The types of drugs that have been used are Amphetamine (shabu-shabu) and methadone. Research conducted by Azriful, Ibrahim, and Sulaiman (2016) on street children in Makassar obtained that from 43 respondents there were 29 people (67.4\%) with an age range of 15-18 years who engaged in inhalation activities. Another study outside Makassar City conducted by Hutami (2014) stated that most of the street children in Semarang City $(72.5 \%)$ of their study samples had used drugs such as injecting drugs, tablets / pills, and sniffing.

Attitude is a reaction or response that is still closed from someone to a stimulus or object. Attitude is a person's feelings, thoughts and tendencies which are more or less permanent about certain aspects in their environment (Montano and Kasprzyk, 2008). Based on the results of research on the attitudes of respondents in the pre-test obtained that the attitudes of respondents are in the category of less $(16.7 \%)$ and good $(83.3 \%)$ then the results of the analysis using paired t-test obtained that there are differences in attitude before and after media intervention audio visual ABAT three times $(\mathrm{p}=0,000$ $<0.05)$. Furthermore, the results of the analysis of differences in attitudes in post test 1 and post test 2 concluded that there was no difference in attitude between the first post test and the second post test $(\mathrm{p}=$ $0.942>0.05)$.

The results of the analysis in the control group also obtained the results that there were differences in the attitudes of respondents before and after being given the audio visual media intervention ABAT one time $(\mathrm{p}=0,000<0.05)$. Furthermore, an analysis of differences in attitude on the second post test was carried out two weeks after the first post test. Although there is only a slight difference in the median value on the first post test and the second post test that is the first post test median value has decreased, but statistically the results are obtained that there are differences in attitude between the first post test and the second post test.

Knowledge, attitude and practice are stages of behavior change or behavior formation. Before a person adopts behavior he must know in advance what the benefits for himself. To realize this knowledge, individuals are stimulated by health education. After someone knows the stimulus, the next process he will assess / behave towards the stimulus. Therefore indicators for health attitudes are also in line with health knowledge (Notoatmodjo, 2012). In this study, both the intervention and control groups together increase respondents 'knowledge about HIV \& AIDS and this is in line with the increase in respondents' attitudes. It can be concluded that the ABAT audio visual media has succeeded in giving influence in increasing respondents' knowledge and attitudes in accordance with Notoatmojo's theory.

This is supported by the research of Yanti, Dewi, and Nurchayati (2015) which states that there is an influence before (pre-test) and after (post test) the provision of health education using audiovisual media on adolescent attitudes compared to the control group (without the provision of health education). The respondent's attitude variable shows that there is a difference in attitude between the intervention group and the control group, or in other words the increase in the attitude of street children about HIV \& AIDS can increase well if the intervention is done more than once.

\section{Conclusion}

Based on the results of the study it can be concluded that audio visual media interventions are three times more effective than interventions as much as one time in improving the attitude of street children in Makassar. Because of this it is necessary to provide health information such as ABAT repeatedly. In addition, further research can also assess changes in adolescent knowledge and attitudes to behavior changes. 


\section{References}

Amiruddin, R., \& Yanti, F. (2013). Tindakan Berisiko Tertular HIV/AIDS Pada Anak Jalanan Kota Makassar. Repositori Universitas Hasanuddin. Available from: http://repository.unhas.ac.id/handle/123456789/6692

Azriful, Ibrahim, I. A., \& Sulaiman, Y. (2016). Al - Sihah : Public Health Science Journal Gambaran Pengguna Narkoba Inhalasi ( Ngelem ) Pada Anak Jalanan di Kota Makassar Tahun 2015. AlSihah: Public Health Science Journal, 8(1), 88-101.

Brooks-Gunn, J., Boyer, C. B., \& Hein, K. (1988). Preventing HIV infection and AIDS in children and adolescents: Behavioral research and intervention strategies. American Psychologist, 43(11), 958.

Harjanti, K. A. D., \& Wongso, L. V. (2017). Apakah anak jalanan perlu diperhatikan dalam penanggulangan AIDS ?. Seri Policy Brief - Pusat Penelitian HIV \& AIDS Unika Atma Jaya , 1-7.

Hutami, G. (2014). Hubungan Perilaku Berisiko dengan Infeksi HIV Pada Anak Jalanan Di Semarang. Jurnal Media Medika Muda, 1-22.

Kemenkes RI. (2018). Laporan HIV AIDS TW 4 Tahun 2017.

Kruger, J. M., \& Richter, L. M. (2003). South African street children at risk for AIDS. Children, Youth and Environments, 13(1), 1-14.

Montano, E., \& Kasprzyk. (2008). Health Behavior and Health Counseling Theory Reserch and Practice. San Francisco: Jossey-Bass.

Notoatmodjo. (2012). Promosi Kesehatan dan Ilmu Perilaku. Jakarta: Rineka Cipta.

WHO. (2018). World Health Statistics 2018 Monitoring Health For SDG's. Available from: http://ejournal.uajy.ac.id/14649/1/JURNAL.pdf

Yanti, E. D., Dewi, Y. I., \& Nurchayati, S. (2015). Pengaruh Pendidikan Kesehatan dengan Menggunakan Media Audiovisual terhadap Pengetahuan dan Sikap Remaja Mengenai Upaya Pencegahan Penyakit Menular Seksual. Jurnal Online Mahasiswa, 2(2), 1048-1057.

\section{Copyrights}

Copyright for this article is retained by the author(s), with first publication rights granted to the journal.

This is an open-access article distributed under the terms and conditions of the Creative Commons Attribution license (http://creativecommons.org/licenses/by/4.0/). 